\title{
CDKN1A Gene
}

National Cancer Institute

\section{Source}

National Cancer Institute. CDKN1A Gene. NCI Thesaurus. Code C17782.

This gene is a regulator of cell cycle progression at the G1 phase of the cell cycle. 